\title{
Cold-Water Coral Habitat Mapping: Trends and Developments in Acquisition and Processing Methods
}

\author{
Aaron $\operatorname{Lim}{ }^{1, *} \mathbb{D}$, Andrew J. Wheeler ${ }^{1,2}$ and Luis Conti ${ }^{3}(\mathbb{D}$ \\ 1 Earth and Environmental Sciences/Environmental Research Institute, School of Biological, \\ University College Cork, T23 TK30 Cork, Ireland; a.wheeler@ucc.ie \\ 2 Irish Centre for Research in Applied Geosciences/Marine \& Renewable Energy Centre, \\ University College Cork, P43 C573 Cork, Ireland \\ 3 Escola de Artes Ciências e Humanidades, Universidade de São Paulo, São Paulo 01000-000, Brazil; \\ lconti@usp.br \\ * Correspondence: aaron.lim@ucc.ie
}

Citation: Lim, A.; Wheeler, A.J.; Conti, L. Cold-Water Coral Habitat Mapping: Trends and Developments in Acquisition and Processing Methods. Geosciences 2021, 11, 9. https://dx.doi.org/10.3390/ geosciences 11010009

Received: 5 November 2020 Accepted: 18 December 2020 Published: 26 December 2020

Publisher's Note: MDPI stays neutral with regard to jurisdictional claims in published maps and institutional affiliations.

Copyright: () 2020 by the authors. Licensee MDPI, Basel, Switzerland. This article is an open access article distributed under the terms and conditions of the Creative Commons Attribution (CC BY) license (https: / / creativecommons.org/ licenses/by/4.0/).

\begin{abstract}
Cold-water coral (CWC) habitats are considered important centers of biodiversity in the deep sea, acting as spawning grounds and feeding area for many fish and invertebrates. Given their occurrence in remote parts of the planet, research on CWC habitats has largely been derived from remotely-sensed marine spatial data. However, with ever-developing marine data acquisition and processing methods and non-ubiquitous nature of infrastructure, many studies are completed in isolation resulting in large inconsistencies. Here, we present a concise review of marine remotelysensed spatial raster data acquisition and processing methods in CWC habitats to highlight trends and knowledge gaps. Sixty-three studies that acquire and process marine spatial raster data since the year 2000 were reviewed, noting regional geographic location, data types ('acquired data') and how the data were analyzed ('processing methods'). Results show that global efforts are not uniform with most studies concentrating in the NE Atlantic. Although side scan sonar was a popular mapping method between 2002 and 2012, since then, research has focused on the use of multibeam echosounder and photogrammetric methods. Despite advances in terrestrial mapping with machine learning, it is clear that manual processing methods are largely favored in marine mapping. On a broader scale, with large-scale mapping programs (INFOMAR, Mareano, Seabed2030), results from this review can help identify where more urgent research efforts can be concentrated for CWC habitats and other vulnerable marine ecosystems.
\end{abstract}

Keywords: cold water corals; mapping; multibeam bathymetry; side-scan sonar; habitats; machine learning; geographic information systems

\section{Introduction}

It is estimated that less than $5 \%$ of the seafloor is mapped at a resolution comparable to similar studies on land [1]. However, over the last few decades, advances in new technology have enabled better exploration of the deep sea, revealing new ecosystems and environments; from micro-organisms' communities at superheated hydrothermal vents to complex, interconnected pelagic habitats. Nevertheless, such limited knowledge of the deep sea limits our capacity to predict the future response of marine organisms' to increasing human pressure and changing environmental conditions [2]. Cold-water coral (CWC) reef habitats are a remarkable example of such ecosystems found in shallow waters to more than $2 \mathrm{~km}$ [3]. Although corals are popularly associated with warm, tropical waters, and exotic fish, it is in the cold and dark waters of the deep ocean, that azooxanthalate CWC species develop reefs which rival their tropical counterparts in terms of species richness and diversity $[4,5]$.

CWCs are long-lived and slow-growing cnidarians, encompassing stony corals (e.g., Scleractinia, with Desmophyllum pertusum, recently synonymized from Lophelia pertusa [6], 
Madrepora oculata and Oculina spp.), soft corals (Octocorallia, including "precious" corals, gorgonian sea fans, and bamboo corals), black corals (Antipatharia), and hydrocorals (Stylasteridae) (see Cairns, (2007) and Roberts et al., (2009) for a review). They grow, in general, where the interaction between topographic heterogeneity and water mass dynamics (bottom currents, internal waves) create moderate to strong hydrodynamics, coupled with the occurrence of hard substrates, a high flux of particulate organic matter (POM) and reduced terrigenous inputs [7-11]. Many CWCs develop calcium carbonate skeletons that trap current-suspended sediments to generate structural habitats like coral gardens, reefs, and mounds [12-14].

Several recent studies have highlighted the environmental importance of CWC habitats as biodiversity hotspots because they develop complex local and regional food chains, serving as important spawning, nursery, and feeding areas for a multitude of fishes and invertebrates [15-18]. In particular, they support speciose, high-biomass ecosystems at water depths where life is otherwise relatively scarce $[5,19]$. Since these communities live in deep, dark parts of the ocean, they possess no light-dependent symbiotic algae (azooxanthellate) and are therefore predominantly dependent on the supply of POM.

Nevertheless, quantitative research and process-oriented analysis that relates CWC structure, geographic distribution, and physical settings (e.g., currents, depth, temperature, geology, and ecology) are scarce due to their complex structure and limited accessibility [17]. Thus, we are still only beginning to understand the specific environmental tolerances of CWCs. It is evident that there are large knowledge gaps which need to be filled by further mapping and integrated, multidisciplinary, and multi-scale research including integrated modeling of distribution, geology, biology, ecology, and the assessment of human impact [20]. Given their occurrence in deep, inaccessible parts of the planet, the most common way of understanding these habitats is through marine remote sensing and subsequent analyses. As such, many studies are completed in isolation and are not comparable due to methods employed or the scale of the research area.

Although there are studies pointing to the regional role of CWC reefs in organic matter cycling and significance in local pelagic benthic couplings [17], the lack of systematic knowledge of the global extent of the oceanic substrate covered by CWC makes it difficult to understand their importance as control agents for biogeochemical cycles and, as a consequence, for global climate change. Nevertheless, CWC are constantly listed as high priority environments for conservation in several international marine environmental protection initiatives as deep sea habitat types of special interest $[15,21]$.

Mapping the distribution of CWCs is therefore, essential for understanding conservation, habitat and organismal tolerances, as well as for marine spatial planning and economic impacts. Here, we present a methodological review of remotely-sensed spatial investigations of CWC habitats and subsequent methods of analysis to show overarching trends in this field. Based on this, we present a perspective on the future needs for mapping CWC habitats which are also relevant to other marine environments.

\section{Future Mapping Perspectives}

Cold-water coral communities are exposed to several types of anthropogenic threats, which include industrial fisheries, hydrocarbon exploration, and mineral resources exploration, as well as global ocean change including warming and acidification [22] and the study of these ecosystems is a challenging task not only because of their inherent complexity but also because of their crucial importance in global ecology and biogeochemistry. In this context, a large number of surveying exploration missions shall be launched in the coming years and new processing and analytical tools will become increasingly important in dealing with the large number of datasets that will be produced.

In 2017, the UN proclaimed the Decade of Ocean Science for Sustainable Development (2021-2030) whose objective is to increase knowledge of the oceans as a basis for the implementation of management and conservation programs. Concurrently, the Nippon Foundation-GEBCO Seabed 2030 Project issued the challenge to survey the ocean floor 
across the globe by 2030 using multibeam sonar (MBES). In addition, inter-governmental agreements, including the Galway Statement (2013) for the North Atlantic and the Belém Statement (2017) for the whole Atlantic, seek to encourage collaborative ocean research with bathymetric mapping [23].

With respect to progress in CWC mapping, all this effort in the coming years should produce an exceptionally large amount of data that will need to be modeled and analyzed [1]. However, it should be noted that there is a large difference in context between different regions of the planet: in the South Atlantic and much of the Pacific and Indian Ocean, where much of the current research is based on punctual data [24-27] or no information whatsoever, the mapping process should have an exploratory approach, in which CWC habitats should be identified, delineated, and characterized. On the other hand, in areas where there are more detailed studies such as the North Atlantic and the Mediterranean, new survey and processing techniques must be developed to investigate more meticulous aspects of the physiology and responses of these ecosystems to local and global environmental changes. In either case, the production of data archives will require the development of new methods of information management, which must be supported by spatial data infrastructures (SDI) and international repositories that can handle the storage and dissemination of this data that can be used to build more complex mapping surveys and modeling.

\section{Surveying Cold-Water Coral Habitats}

Before modern technological advances, the location of CWCs were known from the experiences of fishermen. For example, offshore Norway, where fishing is commonplace, fishermen would note the location of CWCs as it was harmful to their fishing gear [28]. In recent times, the utilization of sonar (e.g., side-scan sonars and MBES) and video data has become common place for mapping CWCs and their habitats which have led to understanding of their occurrence, development, and aspects of their environmental tolerances [29-47].

For CWC habitat mapping, acoustic survey methods are the most common method used for collecting information on the characteristics of coral bioconstructions and the surrounding seafloor context. There are several types of common acoustic surveying methods for benthic characterization and each one brings advantages and disadvantages [48]. Technical specifications and details of different acoustic mapping and background survey methods are not part of the purpose of this review, but additional information can be found in [49-54] and references therein.

Vessel-mounted MBES bathymetric data have been used to measure the gross morphology, distribution, and orientation of large carbonate mounds, for example, in the Belgica Mound Province, NE Atlantic [55], Campeche Mound Province, Gulf of Mexico [56], Mingulay Reef Complex, NE Atlantic [57,58], and Santa Maria Di Leuca, Mediterranean [38]. Vessel-acquired MBES bathymetric data on the European margin show that CWC mound habitats can form "inherited" or "acquired" morphologies where corals either grow upon a suitable substrate and inherit its gross morphology or where they develop mound-shaped features as a result of their interaction with the net hydrodynamic regime respectively [30,59]. Analysis of these data show that coral mound features can be up to $400 \mathrm{~km}$ long and up to $100 \mathrm{~m}$ in height, occupying areas of up to $68 \mathrm{~km}^{2}$ in some regions $[37,60]$. Large coral mound features have been reported to exist as elongate "chains" in the NE Atlantic [55,61].

One major disadvantage of vessel-mounted MBES is that image resolution is a function of water depth: the deeper the water, the more the beams spread out and the lower the resultant map resolution. A corollary to this is that deeper water, also means a larger area of ensonification or swathe wide, hence allowing for greater mapping coverage for survey effort. Therefore, despite advances in MBES echosounder technology increasing resolution and accuracy, vessel-acquired bathymetric data still suit regional seabed mapping exercises with smaller CWC features (i.e., mini-mounds/cold water coral reefs) not readily resolved. 
For example, despite considerable vessel-mounted bathymetric mapping efforts in the Belgica Mound Province, NE Atlantic, it was not until mapping acquisition via the deeptowed TOBI (towed ocean bottom instrument) $30 \mathrm{kHz}$ side-scan sonar that the small-sized Moira Mound cold water coral reefs were identified [39,62]. Perhaps more importantly, by deep-towing side-scan sonars (SSS) closer to the seabed, not only could smaller coral mounds be revealed, but also the sedimentary structures around them [34,63]. Many of these sedimentary structures represent sediment transport (e.g., sediment waves) or erosive benthic conditions (e.g., seabed scour) which demonstrate that CWC habitats typically exist in intensified current regimes [64].

Eventually, autonomous underwater vehicle- (AUV) and remotely operated vehicle(ROV) mounted MBES became technically feasible and overcame the resolution limitations of vessel-based MBES giving control over the survey flight height. Although the intrinsic pay-off between map resolution and swathe remained, users could determine what is more important; survey detail or survey coverage. Furthermore, the advantages of MBES data over SSS data were realized. MBES is spatially consistent and accurate, whereas SSS data suffer from a number of fundamental weaknesses. Firstly, data are poorly positioned with only the nadir beams directly below the sonar fish navigable. Distance away from the nadir is measured in acoustic signal two-way travel time as an estimate for seabed position with an assumed sound velocity. This means that secondly, water column velocity changes produce unresolvable image distortions and geopositioning errors that become more pronounced with increased flight height and distance from the nadir. Thirdly, image resolution also decreases away from the nadir as the beams spread out, and finally, ensonification directions are opposite port and starboard of the nadir cast acoustics shadows in opposing directions. For these reasons, SSS imagery requires expert interpretations whereas MBES image is instantly comprehensible by the lay-viewer and georeferenced digital data easily transformed into 3D models (called digital terrain models or DTMs) or other derived products. Despite an improved product, the disadvantages of MBES over SSS are increased costs, swath coverage, logistics, and computational requirements.

The application of AUV-bathymetric surveys (MBES) revealed that CWC mounds exhibit a diverse morphological variation even across relatively small areas (e.g., NW Atlantic) [29]. ROV-mounted MBES bathymetric data in the NE Atlantic demonstrates similar CWC mound morphological diversity, shows the potential for these mound features to influence their own sedimentary environment [65], their ability to survive environments with high sediment bedload transport [66], and their occurrence on vertical submarine cliff-face exposures [33]. Use of ROV- and AUV-mounted MBES have an advantage over deep-towed side scan sonars as they provide morphological (bathymetric) as well as textural (backscatter) information.

Video and image data, recorded with AUVs, ROVs, towed video and drop cameras have been utilized to describe CWC habitats in great detail. This includes the quantification of the abundance of live coral $[57,67,68]$, benthic habitat characterization [69] and moundscale sediment facies distribution [32,70]. However, many of these studies extrapolate findings from image data across considerably lower resolution bathymetric data. As such, there is a need for more local scale studies with data sets (e.g., image and bathymetric data) of a comparable resolution [71].

Manually generated image mosaics have been utilized to demonstrate the interaction of the current with coral frameworks as evidenced by ripple type and orientation [72]. However, these image mosaics typically cover relatively small areas. More recently, 2D photogrammetry via image mosaicking has been successfully applied to ROV image data from CWC habitats e.g., the Piddington Mound, NE Atlantic [73]. The analysis of such data has shown that these CWC habitats can exhibit spatial patterns that reflect fine-scale processes. More recently, structure-from-motion (SfM) photogrammetry, which produces 3D point clouds, orthorectified imagery, and associated digital elevation models, is accurate, precise, and repeatable [74] and has been used to quantify fine scale structural complexity within cold water coral habitats $[75,76]$. 
Progressively higher resolution mapping and ever-developing underwater positioning technologies [77,78] allow effective repeat mapping, which can be utilized to monitor the temporal dynamics in CWC habitats. Repeat SSS mapping at the Darwin Mounds, NE Atlantic demonstrates the low-recovery rates of trawled CWC habitats over a period of 8 years [20]. Repeat video-mosaic imaging the Piddington Mound in the NE Atlantic show that even changes in biodiversity and sediment facies can be significant over just 4 years $[79,80]$. Similar temporal studies using structure from motion photogrammetry have also been completed on octocorals [81].

With methods of mapping acquisition varying from vessel-mounted MBES to ROVimage photogrammetry, the methods of analyzing these data also vary considerably. Further, with advances in geographical information science and spatial analyses, analyses of these data have evolved considerably [82]. Typically, earlier processed data were visualized within a geospatial environment, where seabed features were visually inspected and interpreted manually [64]. When ROV video data was incorporated into these efforts, the video data were inspected and classified in a standardized methodology [69]. Often, these video observations were plotted as points $(x, y)$ whose attributes were then extrapolated across SSS derived backscatter based on pixels of similar spectral properties [83].

While these manual approaches have similar accuracies to automated methods, they are considerably more time consuming and therefore automated approaches are more viable for mapping CWC habitats over large areas [41]. A broad-scale classification of mounds and associated seabed features has been demonstrated in the NE Atlantic (e.g., buried mound and channels) [84]. To do this, they outline an angular backscatter normalization workflow and show that coral mound features can clearly be identified in this way. A multivariate method, ecological niche factor analysis (ENFA), has been widely used for identifying suitable cold water coral habitats based on presence-only predictor variables. In the NE Atlantic, ENFA has been applied to bathymetry at multiple scales (ROV- and vessel-mounted) coupled with ROV-video data, where terrain variables were used as predictor values and have shown to be effective at both local and regional scales [31,71]. ENFA has also been applied at global and regional scales using publicly available oceanographic data to show that the $\mathrm{N}$ Atlantic Ocean is the most suitable region for Desmophyllum pertusum, the main framework-forming CWC [85]. However, Davies et al. [85] also note that at a global scale, predictions are less reliable given the lack of data outside of the NE Atlantic region.

A list of studies whose primary methods utilize spatial mapping and processing of CWC habitats are presented in the Table 1 . These studies are utilized herein to highlight trends in acquisition and processing methods for CWC habitat mapping. As such, the criteria for studies to be included: (a) are peer-reviewed publications of CWC reef or mound habitats; (b) published no earlier than the year 2000 to highlight recent developments; (c) should present the acquisition and processing of spatial, georeferenced raster data that have been used as a primary dataset in the study and; $(d)$ processing methods should not include point (vector) observations derived from video or physical samples. Figure 1 summarizes the most frequent words within these publications. The lexical analysis was based on the algorithm that calculates all occurrence of relevant words in the reference articles [86]. 


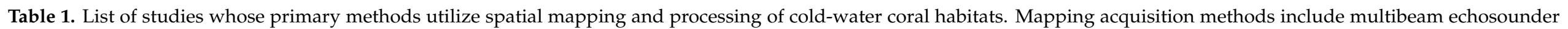

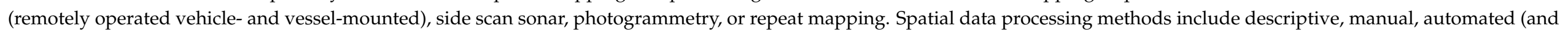
semi-automated), and machine learning.

\begin{tabular}{|c|c|c|c|c|c|c|c|c|}
\hline Article & Year & Journal & Video/Image & MBES & ROV MBES & Photogram & SSS & Place \\
\hline Huvenne et al., 2002 [63] & 2002 & Marine Geology & 0 & 0 & 0 & 0 & 1 & NE Atlantic \\
\hline De Mol., et al., 2002 [87] & 2002 & Marine Geology & 0 & 0 & 0 & 0 & 1 & NE Atlantic \\
\hline Masson et al., 2003 [89] & 2003 & Marine Geology & 1 & 0 & 0 & 0 & 1 & NE Atlantic \\
\hline Beyer et al., 2003 [55] & 2003 & Marine Geology & 0 & 1 & 0 & 0 & 0 & NE Atlantic \\
\hline O'Reilly et al., 2003 [90] & 2003 & Marine Geology & 0 & 0 & 0 & 0 & 1 & NE Atlantic \\
\hline Kenyon et al., 2003 [91] & 2003 & Marine Geology & 1 & 0 & 0 & 0 & 1 & NE Atlantic \\
\hline Akhmetzhanov et al., 2003 [92] & 2003 & in Mienert and Weaver eds. & 0 & 0 & 0 & 0 & 1 & NE Atlantic \\
\hline Foubert et al., 2005 [93] & 2005 & in Freiwald and Roberts (eds) & 1 & 0 & 1 & 0 & 0 & NE Atlantic \\
\hline Huvenne et al., 2005 [34] & 2005 & in Freiwald and Roberts (eds) & 1 & 0 & 0 & 0 & 1 & NE Atlantic \\
\hline Roberts et al., 2005 [58] & 2005 & Coral Reefs & 1 & 1 & 0 & 0 & 0 & NE Atlantic \\
\hline Wheeler et al., 2005 [62] & 2005 & in Freiwald and Roberts (eds) & 1 & 1 & 0 & 1 & 1 & NE Atlantic \\
\hline Grasmueck et al., 2006 [29] & 2006 & Geophysical Research Letters & 0 & 0 & 1 & 0 & 0 & NW Atlantic \\
\hline Wheeler et al., 2007 [30] & 2007 & Int Journal of Earth Sciences & 1 & 1 & 0 & 0 & 1 & NE Atlantic \\
\hline Dorschel et al., 2007 [70] & 2007 & Marine Geology & 1 & 0 & 0 & 0 & 1 & NE Atlantic \\
\hline De Mol et al., 2007 [95] & 2007 & Int Journal of Earth Sciences & 1 & 1 & 0 & 0 & 1 & NE Atlantic \\
\hline Dolan et al., 2008 [71] & 2008 & Deep Sea Research 1 & 1 & 0 & 1 & 0 & 0 & NE Atlantic \\
\hline Wheeler et al., 2008 [96] & 2008 & Sedimentology & 0 & 0 & 0 & 0 & 1 & NE Atlantic \\
\hline Dorschel et al., 2009 [64] & 2009 & Marine Geology & 1 & 0 & 0 & 0 & 1 & NE Atlantic \\
\hline Wienberg et al., 2009 [97] & 2009 & Deep Sea Research 1 & 1 & 0 & 0 & 0 & 0 & NE Atlantic \\
\hline Guilloux et al., 2009 [29] & 2009 & Deep Sea Research 2 & 1 & 1 & 0 & 0 & 1 & S Atlantic \\
\hline Guinan et al., 2009 [98] & 2009 & Marine Ecology Press Series & 1 & 1 & 0 & 0 & 0 & NE Atlantic \\
\hline Guinan et al., 2009 [31] & 2009 & Ecological Informatics & 1 & 1 & 0 & 0 & 0 & NE Atlantic \\
\hline
\end{tabular}


Table 1. Cont.

\begin{tabular}{|c|c|c|c|c|c|c|c|c|}
\hline Article & Year & Journal & Video/Image & MBES & ROV MBES & Photogram & SSS & Place \\
\hline Heindel et al., 2010 [32] & 2010 & Continental Shelf Research & 1 & 1 & 0 & 0 & 0 & NE Atlantic \\
\hline Savini et al., 2010 [38] & 2010 & Deep Sea Research 2 & 0 & 1 & 0 & 0 & 1 & Mediteranean \\
\hline Davies et al., 2010 [99] & 2010 & Deep Sea Research 1 & 1 & 1 & 0 & 0 & 0 & NW Atlantic \\
\hline Wheeler et al., 2011 [72] & 2011 & Marine Geology & 1 & 0 & 0 & 1 & 1 & NE Atlantic \\
\hline Foubert et al., 2011 [66] & 2011 & Marine Geology & 1 & 0 & 1 & 0 & 0 & NE Atlantic \\
\hline Coiras et al., 2011 [100] & 2011 & $\begin{array}{l}\text { IEEE Journal of Selected Topics } \\
\text { in Applied Earth Observations } \\
\text { and Remote Sensing }\end{array}$ & 1 & 1 & 0 & 0 & 0 & Mediteranean \\
\hline Correa et al., 2012 [101] & 2012 & Marine Geology & 1 & 0 & 1 & 0 & 1 & NW Atlantic \\
\hline Correa et al., 2012 [102] & 2012 & Sedimentology & 1 & 1 & 0 & 0 & 1 & NW Atlantic \\
\hline Mazzini et al., 2012 [103] & 2012 & Geo-Marine Letters & 1 & 1 & 0 & 0 & 1 & NE Atlantic \\
\hline Harris et al., 2012 [104] & 2012 & Seafloor Geomorphology & 1 & 1 & 0 & 0 & 0 & S Pacific \\
\hline Wienberg ET AL., 2013 [106] & 2013 & Biogeosciences & 1 & 1 & 0 & 0 & 0 & NE Atlantic \\
\hline Mienis et al., 2014 [107] & 2014 & Biogeosciences & 1 & 1 & 0 & 0 & 0 & NW Atlantic \\
\hline Hebbeln et al., 2014 [56] & 2014 & Biogeosciences & 1 & 1 & 0 & 0 & 0 & NW Atlantic \\
\hline Brooke et al., 2014 [108] & 2014 & Deep Sea Research 2 & 1 & 1 & 0 & 0 & 0 & NW Atlantic \\
\hline Savini et al., 2014 [37] & 2014 & PLOS One & 1 & 1 & 0 & 0 & 1 & Mediteranean \\
\hline Lo Iacono et al., 2014 [109] & 2014 & Deep Sea Research 2 & 0 & 1 & 0 & 0 & 0 & Mediteranean \\
\hline Neves et al., 2014 [110] & 2014 & Deep Sea Research 2 & 1 & 1 & 0 & 0 & 0 & NW Atlantic \\
\hline Somoza et al., 2014 [111] & 2014 & Marine Geology & 0 & 1 & 0 & 0 & 0 & NE Atlantic \\
\hline Mackay et al., 2014 [112] & 2014 & $\begin{array}{l}\text { New Zealand Journal of Marine } \\
\text { and Freshwater Research }\end{array}$ & 1 & 1 & 0 & 0 & 0 & S Pacific \\
\hline Stewart et al., 2014 [113] & 2014 & Deep Sea Research 2 & 1 & 1 & 0 & 0 & 0 & NE Atlantic \\
\hline Robert et al., 2016 [114] & 2016 & Deep Sea Research 1 & 1 & 1 & 0 & 0 & 1 & NE Atlantic \\
\hline Huvenne et al., 2016 [20] & 2016 & Biological Conservation & 1 & 0 & 0 & 0 & 1 & NE Atlantic \\
\hline
\end{tabular}


Table 1. Cont

\begin{tabular}{|c|c|c|c|c|c|c|c|c|}
\hline Article & Year & Journal & Video/Image & MBES & ROV MBES & Photogram & SSS & Place \\
\hline Vandthorpe et al., 2016 [115] & 2016 & Marine Geology & 0 & 1 & 0 & 0 & 0 & NE Atlantic \\
\hline De Clippele et al., 2016 [57] & 2016 & Coral Reefs & 1 & 1 & 1 & 0 & 0 & NE Atlantic \\
\hline Lim et al., 2017 [73] & 2017 & Marine Geology & 1 & 0 & 1 & 1 & 0 & NE Atlantic \\
\hline Robert et al., 2017 [76] & 2017 & Nature Sci Reports & 1 & 0 & 1 & 1 & 0 & NE Atlantic \\
\hline Ramos et al., 2017 [116] & 2017 & in Ramos, Ramil and Sanz (eds) & 0 & 1 & 0 & 0 & 0 & NE Atlantic \\
\hline Reolid et al., 2017 [117] & 2017 & Facies & 1 & 1 & 0 & 0 & 0 & Indian Ocean \\
\hline Lim et al., 2018 [65] & 2018 & Marine Geology & 1 & 0 & 1 & 1 & 0 & NE Atlantic \\
\hline Lim et al., 2018 [80] & 2018 & Marine Geology & 1 & 0 & 1 & 0 & 0 & NE Atlantic \\
\hline Collart et al., 2018 [118] & 2018 & Progress in Oceanography & 1 & 1 & 0 & 0 & 0 & NE Atlantic \\
\hline Diesing et al., 2018 [119] & 2018 & Marine Geomorphometry & 0 & 1 & 0 & 0 & 0 & NE Atlantic \\
\hline Conti et al., 2019 [120] & 2019 & Nature Sci Reports & 1 & 0 & 1 & 1 & 0 & NE Atlantic \\
\hline Hebbeln et al., 2019 [121] & 2019 & Marine Geology & 1 & 1 & 0 & 0 & 0 & NE Atlantic \\
\hline Price et al., 2019 [75] & 2019 & Coral Reefs & 1 & 0 & 0 & 1 & 0 & NE Atlantic \\
\hline Lim et al., 2020 [122] & 2020 & Nature Sci Reports & 1 & 1 & 0 & 1 & 0 & NE Atlantic \\
\hline
\end{tabular}




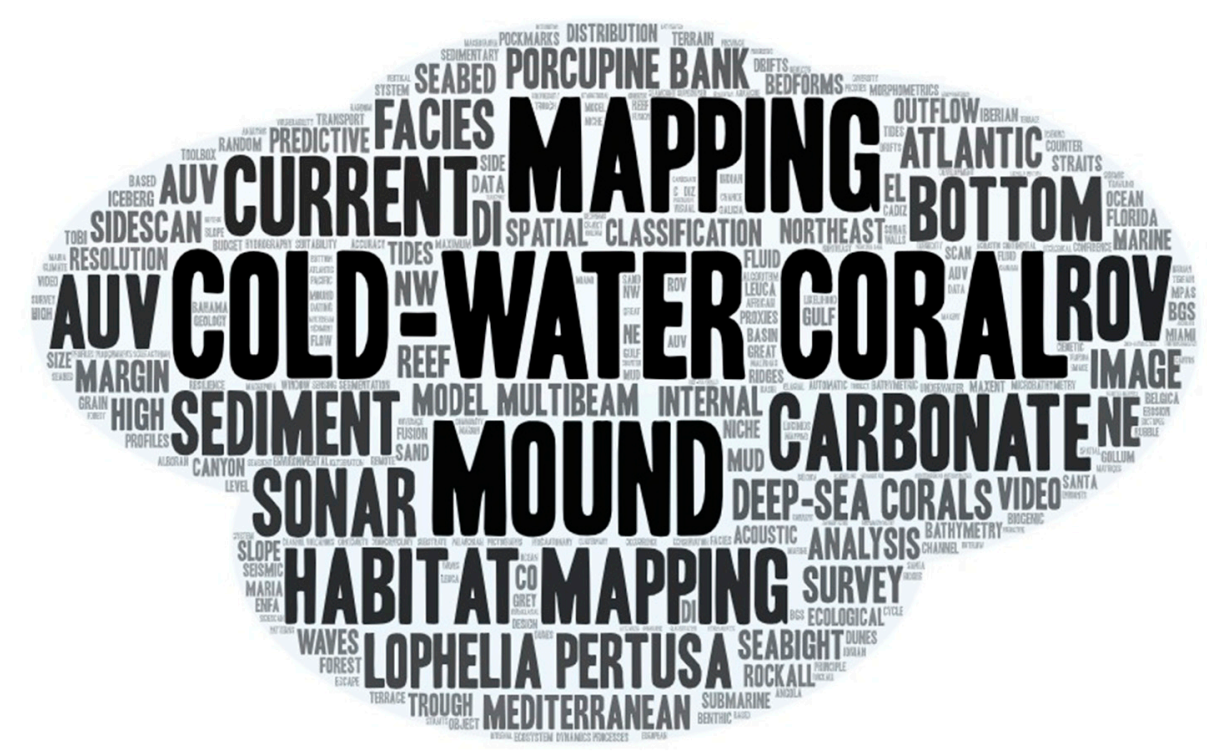

Figure 1. Word cloud of the most frequent significant terms in the reviewed articles.

\section{Acquisition Methods}

Research on CWC habitats have utilized spatial mapping methods at various resolutions and scales in many parts of the world's oceans (Table 1). Many of these efforts have been in the NE Atlantic where CWC habitats have been consistently mapped since 1997 (results first published in Kenyon et al. [123]), although CWC mapping results in the Gulf of Mexico were first published in 1985 [124] and continue episodically in the Gulf and NW Atlantic thereafter. Although this research has been continuous although intermittent at the start, there are regional and temporal difference in (Figure 2). Following USA and European initiatives, there has been an increase in similar studies in other regions also (S Atlantic, Mediterranean, S Pacific, and Indian Ocean). These efforts are not synchronous, but rather have a stepped onset (NW Atlantic, S Atlantic, and Mediterranean consecutively). Although it is unclear why initial studies and discoveries in the USA did not lead to sustained surveying efforts, it may have been that deep-tow SSS acquisition and processing (MBES did not become mainstream until the late 1990s) was still in its infancy and technically challenging in the deep sea. In Europe, the hydraulic model proposed by Hovland and Thomsen [125] led to an "explosion" of interest and EU funding at a time when deep sea seabed mapping technology was able to produce meaningful results. The longevity and consistency of mapping CWC habitats is probably significantly influenced by the availability of infrastructure and fund trends of host administrations. Despite limited early effort, US CWC surveying publications become more numerous under the second Bush administration (2001-2009) with a notable increase in effort under the Obama administration (2009-2017) followed by a cessation in the late Obama and Trump (2017-present) administrations. The increase in the publications in survey results do not seem to be affected by global economic downturn in 2008 and subsequent years with a constriction in European NE Atlantic publications over-compensated by a burst in Mediterranean publications. Later and short-lived interest in S Atlantic, S Pacific, and India Ocean may be a result of an eventual spread of global interest and a desire to fund innovative "virgin territory" research with potential for major discoveries.

Figure 2 clearly demonstrates Atlantic-centric cold-water coral spatial mapping research efforts since 2002 with a particular emphasis on the NE Atlantic. This may lead to bias in understanding of cold-water coral habitats in a global context. However, it does provide a rich baseline of data for continued and more advanced research in the region. Trials for new CWC mapping methods can be compared against these baseline data. Uniquely, given a 17-year record of mapping efforts, many of the study sites within 
the NE Atlantic may offer the opportunity for repeat mapping at various temporal and spatial scales not accessible anywhere else.

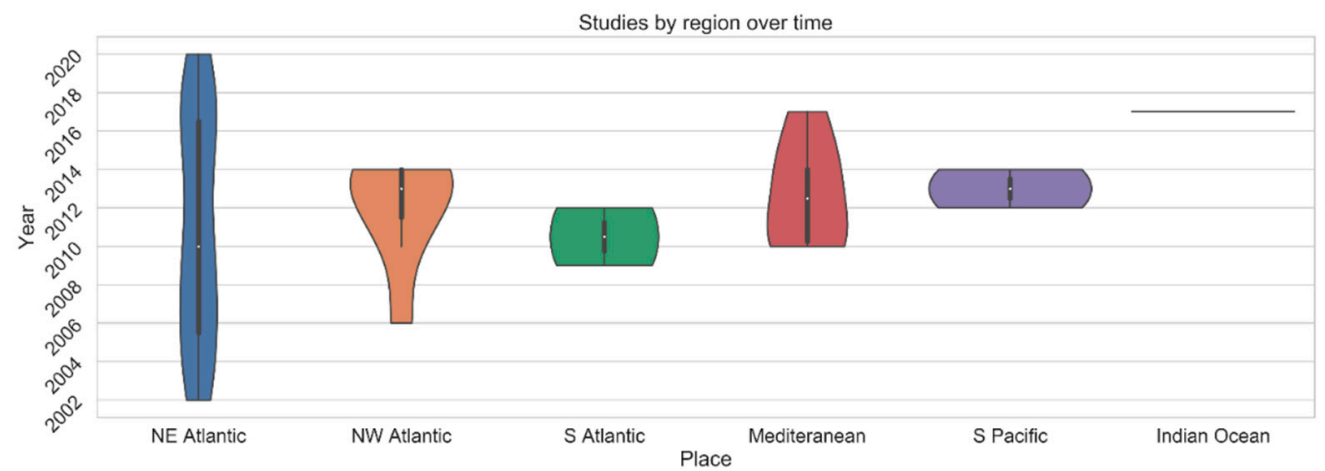

Figure 2. Violin plot visualizing the studies whose primary methods utilize spatial mapping and processing of CWC habitats since 2002.

Mapping acquisition methods in cold water coral habitats range widely from SSS to photogrammetry, and from hull- and ROV-mounted MBES to repeat mapping in general. Side-scan sonar data were widely used in early CWC habitat mapping efforts, especially in the NE Atlantic [62,63]. The ability to deep-tow side scan sonars results in relatively high-resolution spatial data sets (e.g., 0.35 m; Masson, et al. [89]) when compared to hullmounted mapping efforts around the same period of time (e.g., 25 m; Beyer, et al. [55]). Although research utilizing SSS in CWC habitats have been used within a biological context (e.g., Huvenne, et al. [20]), it is more extensively used for predominant geoscience studies $[30,64,96,103]$. Compared to other mapping methods (e.g., MBES and photogrammetry), SSS is less expensive and requires less setup and post processing while providing high spatial resolution dataset. Figure 3 shows that the number of studies utilizing SSS data has decreased overall from 2002 to 2019, being replaced over the same period by studies utilizing MBES have increased. Seventy-six percent of the total studies in Table 1 have utilized MBES. Utilization of hull-mounted MBES data in CWC habitats has increased consistently since 2003 (e.g., [55]). This coincides with the onset of national MBES bathymetric mapping programs within the NE Atlantic where data have been made publicly available e.g., the Irish National Seabed Survey (2000), INFOMAR (2005), and Mareano (2005). Although not all published studies utilize bathymetric data from government funded programs, the progressive use of bathymetric data has made the benefits of such data well-known. As such, freely available data and large government funded programs may play a large but difficult-to-quantify role in understanding modern seafloor habitats.

Despite an overall increase in the number of studies utilizing hull-mounted MBES, there has been a slight decline since 2015. During this period, there has also been an increase in several other mapping methodologies including ROV-mounted MBES [57,65], photogrammetry $[73,75,120]$, and repeat mapping $[20,80]$. Many of these mapping methods are reliant on ROV's with high resolution positioning which have more recently been available [126]. ROV-mounted MBES data acquisition has revealed morphologies of smallsized cold-water coral reefs e.g., the Moira Mounds and mini-mounds at the Mingulay Reef Complex, that were previously not resolvable with traditional hull-mounted MBESs in deep waters. Similarly, photogrammetry has been used to map the distribution of smaller scale CWC habitat features (e.g., Desmophyllum pertusum frameworks and rubble). The recent use of SfM photogrammetry in marine settings requires ROV-derived video footage and high-quality tow-video, although it offers a more affordable option when compared to resolution and cost of ROV-mounted MBES. Photogrammetry, however, can be processingheavy and, although achieves a higher resolution, it typically covers a smaller spatial area. The increase in studies using these higher resolution options has allowed for more local- 
scale studies of CWC habitats in the deep sea, greatly assisted by advances in underwater positioning [126].

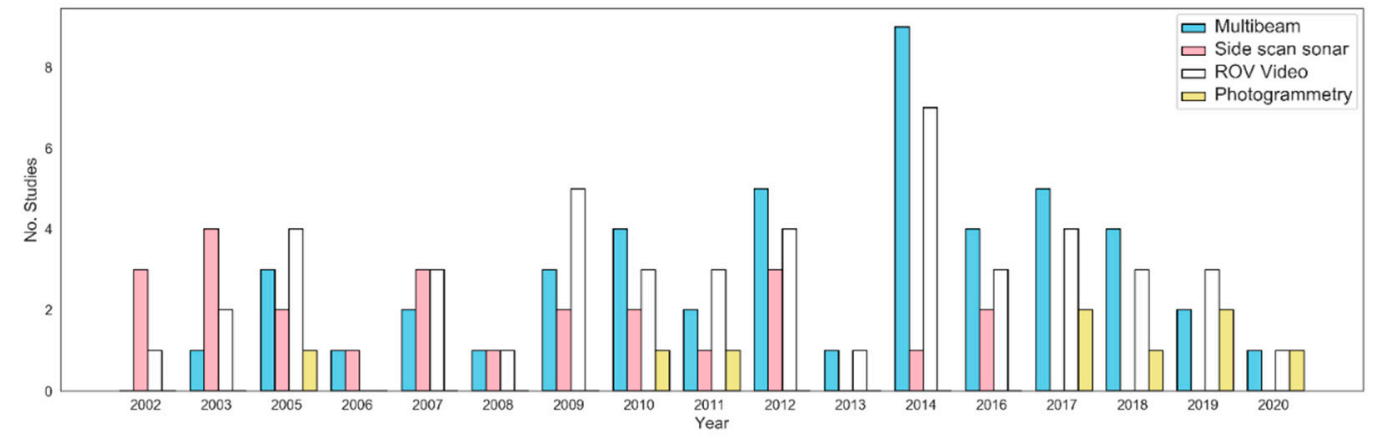

Figure 3. Bar plot showing acquisition methods utilized in cold water coral habitats through time.

CWC habitats rely on currents for continued growth and with global-scale increases in circulation in the upper $2000 \mathrm{~m}$ of the ocean [127], amongst other well-documented marine environmental changes, there has been more interest for marine environmental monitoring through repeat mapping. Repeat mapping requires the study area to be re-mapped with the same methodology and level of accuracy. Given the cost, time, and weather-dependency of marine surveying, this is not common. The only re-mapping efforts for CWC habitats were in the Darwin Mounds (side scan sonar [20]) and the Moira Mounds (Photogrammetry [80]), both within the NE Atlantic. Both of these studies utilize higher resolution methods $(<1 \mathrm{~m}$ pixel resolution) to detect changes that occur over short timescales. Perhaps, in time, hullmounted MBES surveys which are lower resolution (typically $25 \mathrm{~m}$ pixel resolution) will be used to detect large scale changes over longer timescales. As such, given the number of studies reported within the NE Atlantic, these can be revisited to provide a temporal context. The two aforementioned studies were from 2016 and 2018 respectively with other research also discussing the significance of change on a CWC reef (NE Atlantic) albeit using a statistical approach [79].

The number of mapping methods available since 2002 have increased overall (Table 1, Figure 3). Although the methods are changing, this suggests that research is becoming more multi-scaled and diverse within CWC habitats.

\section{Processing Methods}

Spatial data processing exercises applied to CWC mapping, as well as most other seabed mapping exercises in general, are largely based on methods developed for terrestrial mapping, although there are significant differences between satellite-based remote sensing and acoustic datasets with regards to data availability, temporal and spectral resolution [128]. With regards to backscatter data (function of true angle of insonification across the seafloor $[129,130]$, arguably the most important proxy for substrates and benthic habitat characterization, general analyses have fair to modest reproducibility. This condition is largely explained by the lack of control standards in calibration, acquisition, and first-level processing steps and also the incomplete understanding of the theory of the relationships between acoustic propagation and its interaction with the substrate, which makes it difficult to establish libraries and protocols for automatic classification from different acquisition systems (as they occur in well-known spectral libraries in terrestrial remote sensing data). The work of [130] offers a complete discussion about this subject. Thus, spatial data processing in CWC habitats based on both side scan sonar and multibeam backscatter data has been dominated by descriptive processing (Figure 4) where spatial data is plotted and then described qualitatively based on individual measurements or visual assessment. 


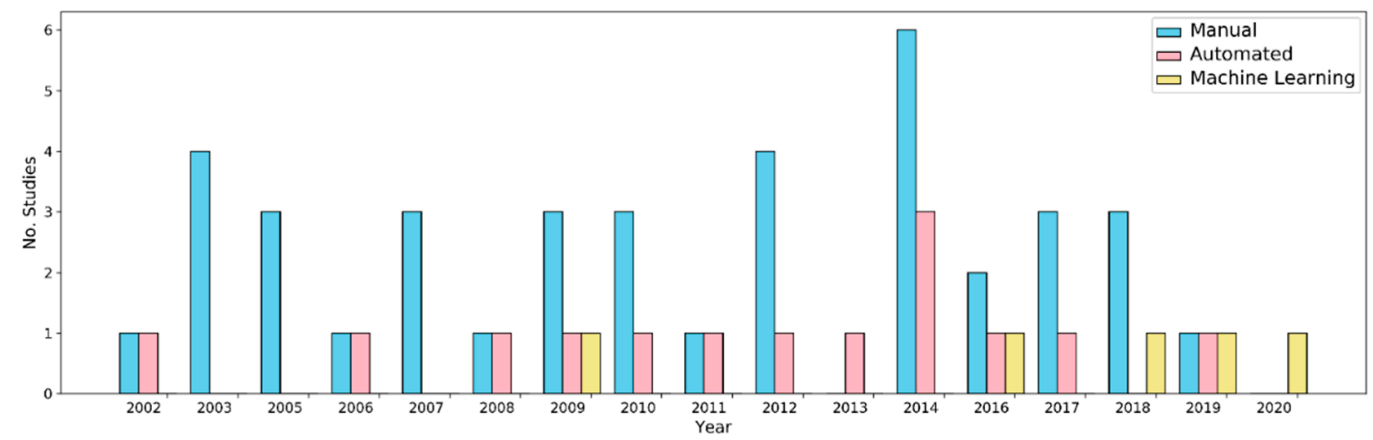

Figure 4. Bar plot showing number of processing methods applied to multibeam echosounder, side scan sonar, photogrammetry, and repeat mapping in CWC habitats.

Descriptive processing was used to describe CWC mound size, morphology and distribution [30], sedimentary bedforms [64] and sediment types surrounding CWC mounds [89], and widely used through observational studies to broad exploratory data [131]. The benefits of descriptive processing are that, rather than needing advanced technical processing skills, it requires only a knowledge of the subject matter (geosciences, life sciences etc.) to be able to interpret the object in question which will allow further contextualization of the study area. In addition, the inherent across beam artefacts in SSS data negate robust geospatial analysis and lend themselves to expert descriptive interpretations. Descriptive methods typically lack the ability to precisely quantify the area covered or sizes of objects in space.

At a higher level of descriptive analysis, objects or features can be manually delineated within a map or a geographic information system. This can then allow characterization, quantification, and visualization of the space occupied by features of interest. This type of processing has been applied to bathymetric and SSS CWC habitat data on the Angolan margin to visualize the area occupied by CWC mounds and their relationship to pockmarks [26]. Similarly, manual recognition has been used to outline the spatial distribution of CWC mounds, tectonic, erosional, and depositional seabed geological features [118]. As well as its time-consuming nature, manual recognition expert-induced classification bias is possible, which causes errors with detection of features and their correct classification [132]. However, this can be minimized by applying a standardized workflow to the dataset. For example, previous research [69] applied a standardized manual recognition method to ROV video data which allowed the authors to quantify coverage of coral across a relatively large area. Manual recognition methods typically require a more detailed understanding of geographic information as well as some technical skill which may explain why it has been utilized less than descriptive processing (Figure 4).

Manual recognition is time-consuming and can be subjective. Automated and semiautomated processing methods have been developed to speed up this process as well as make it more objective and efficient. Some examples of this are pixel and object-based classification methods. Pixel-based classification methods assign the digital numbers associated within a raster (or set of rasters) to a pre-defined class based on its value and are typically applied in benthic habitat mapping context, where the term "habitat" is defined as both the physical and environmental conditions that support a particular biological community together with community itself [48] and the term is commonly used synonymously with "biotope" [133]. In these cases, raster information layers are combined pixel by pixel in order to generate an output raster that, ideally, should be derived from well-developed models linking physical factors to biological data. Pixel-based classification has been applied to bathymetric data of CWC habitats [41]. Of note, Savini et al. [37] applied a maximum likelihood pixel-based classification of the North Ionian Sea, Mediterranean which identifies 5820 coral mound-like features and has shown to be useful to marine spatial planning. 
As previously discussed, the primary data source for CWC habitat mapping are acoustic sources, typically and predominantly now MBES [134,135]. Such systems produce two basic types of information, the depth of the water column or bathymetry (and their derivatives surfaces as slope, aspect, curvature etc.) and backscatter. In both instances (bathymetry and backscatter), individual "pixel" information alone does not bring the possibility of interpretation of the CWC substrate coverage (as in the case of multi-parametric analysis in terrestrial areas) in most cases. Thus, the use of regional analyses is necessary where a set of geographically grouped pixels represent a meaningful unit. This process is called segmentation and it can be done by two main strategies. Firstly, from a generalized criteria of grouping information (bathymetry and derivatives) as classes, as is the case with "benthic terrain modeler" (BTM) [136] which uses a combination of derived terrain attributes to segment the seafloor into geomorphic classes according to pre-determined parameters, loaded from a user defined library. Secondly, by the extraction of segments by growing areas of specific similarities, part of an OBIA (object-based image analysis) method.

Once the segments are established, it is possible to classify them according to the common characteristics that aggregate information to each of these areas. In the case of semi-automated segmentation (e.g., BTM), the geomorphological classes are associated with certain pre-established features such as flats, slopes, ridges (only with specific parameters adjusted for the area in question). Such an approach is purely geomorphological and usually considers only the topographic parameters of the terrain. Thus, in general, identified (classified) features tend to have a clearer "functionality" or "meaning" and are also associated with a specific scale and resolution. In the case of CWC, descriptive models such as BTM are usually used in the geomorphological contextualization of coral habitats [137], in the identification of mounds or other topographic features directly associated to the coral formations or environmental (niche) modeling [138].

In the case of segmentation (e.g., the OBIA methodology), there is no pre-defined parameter for segment generation, so in many cases, the backscatter and visual data (video/camera imagery) have been used in conjunction with the bathymetry in the generation of these geo-objects [139]. To provide a meaningful spatial partitioning, the resulting objects should be identical or at least quite similar in a given class of objects and at aiven scale [140]. Further, since the process does not consider "a priority" of specific characteristics of the substrate, it is necessary to implement classification techniques to establish meaningful relationships between the objects and what they represent. This process is usually carried out from supervised methods where regions of interest (ROIs) are identified as training areas for an algorithm to recognize patterns of similarity and hence the generation of benthic area maps. As OBIA analyses are more generic and scale independent, in the case of CWC, studies have applied segmentation/classification not only at the habitat level but also in the identification of facies [120] and also on a regional scale [43,47]. It is worth mentioning that while the segmentation component of OBIA is an automated process, the classification algorithm can fall under the category of machine learning (support vector machine, random forest, neural networks, etc.). Similarly, object-based approaches have been used to show the presence or absence of CWC mounds with high spatial accuracy across $918 \mathrm{~km}^{2}$ [119].

For supervised classification as well as for robust characterization of CWC habitats, machine learning (ML) processes have been widely used in the integration of many parameters in the search to identify patterns and establish multiparameter models. ML is a set of processes that allow a system to automatically learn from data, resulting in the classification or prediction of test data which has also been widely used in the natural sciences [141]. ML has already been applied to spatial data from CWC habitats but considerably less than manual and automated methods (Figure 4). Ecological niche modeling based on a genetic algorithm for rule-set prediction (GARP) and MaxEnt have been used to predict suitable CWC on Ireland's Continental Margin based on variables like temperature, salinity, BPI (bathymetric position index), terrain rugosity, slope with over $85 \%$ accuracy [31]. ML can also be applied to very high-resolution data. Similarly, an entire CWC reef ( $60 \mathrm{~m}$ by $40 \mathrm{~m}$ ) 
and its facies were classified using object-oriented classification with deep neural network, log regression, and random forest algorithms [120]. The authors report that deep neural network (DNN) was the most appropriate machine learning classification for these types of data. DNN was also used to train and test automatic coral framework recognition to characterize the coral habitat and estimate the coral coverage in a CWC reef [67]. Although this method slightly underestimated coral coverage in some cases, it was able to detect small, live coral fragments more accurately. ML methods have also been applied to other types of non-spatial CWC data. For example, an array of sensors, including HD cameras mounted on a fixed position (i.e., underwater observatory) were utilized to monitor coldwater coral reefs [142]. The authors used deep neural network, logistic regression, and support vector machines to correlate time-series and multi-parameters (e.g., chlorophyll, turbidity, salinity, currents) of specific polyps and structures to understand the dynamics of metabolic and behavioral aspects in relation to the characteristics of the surrounding environment over short (hours and days) and long (years) temporal scales. For ecological mapping (niche scale), the major application of ML methods is related to the integration of different types of data to predict or map variability in coral structure and distribution in relation to environmental or morphosedimentary parameters in structural habitats or ecoregions like coral gardens, reefs, and mounds.

\section{Concluding Remarks}

The progress and advancement of CWC habitat mapping has been driven by advances in technology, underpinned by increasing computation power. It is likely that this trend will continue and perhaps accelerate as global attention turns to increase seabed mapping effort through national and global mapping programs to identify, manage, and secure future resources. Increased data storage and accessibility through cloud computing and open access internet portals makes the derived data product production increasingly feasible.

Early CWC habitat mapping was dependent on, often crude, deep-tow SSS with poor navigation. Increasing computation power made MBES acquisition pragmatic, providing new geographically accurate mapping data. Although accompanied by increased costs of acquisition and greater data processing demands, it is encouraging that the scientific community embraced this technology, overcame these challenges in order to produce better and new data products in a quest to answer the new innovative questions that could now be posed. Limitations of vessel-based acquisition were overcome by further technical advances in taking MBES systems sub-sea on ROVs and AUVs.

Likewise, video and camera seabed image has benefited from increased computational power with the development of photo-mosaicing software and the ability to build larger byte-intensive photomosaics. SfM image rectification now offers the possibility to map optically in three-dimensions at extremely high resolution for small areas. With most archived video data unprocessed, the potential to revisit earlier studies and re-map in higher resolution is now a reality and of huge potential.

The progression from SSS to MBES to SfM also sees a development from 2D to 3D datasets. Forward-facing MBES are now exploring cryptic vertical cliffed CWC habitats [33] and underwater LIDAR may also become more prevalent as this technology is starting to be employed.

Despite trends driven by technological advances, the geopolitics of funding also play a role in surveying activity globally. The desire to be innovative and explore "virgin" CWC areas may see further interest in the $\mathrm{S}$ Atlantic, Indian, and Pacific Oceans. Trends suggest the NE Atlantic and Mediterranean CWC mapping effort will continue to be a promising playground for new innovative mapping and processing products.

Advances in computer processing have also led to a development from qualitative descriptive analysis to more quantitative automated analyses. Such trends should only continue with image-based ML offering new potential for further studies. The move from 2D SSS mapping to 3D MBES, SfM and LIDAR in structurally complex CWC habitats opens the potential to move away from the tradition of data products projected as $2 \mathrm{D}$ 
maps. Working in 3D with 3D object-based analysis with on-line data visualization tools to assist publications opens the potential for more realistic and meaningful appraisal of these structural complex habitats. In this way, we see continued develops in CWC habitat mapping driven by emerging technologies to deliver innovative and more reliable data products to better unpin the management and our understanding of this important habitats in a changing ocean.

Author Contributions: Conceptualization, A.L. and A.J.W.; methodology, L.C.; formal analysis, A.L. and A.J.W.; writing-original draft preparation, A.L.; writing—review and editing, A.L., A.J.W. and L.C.; supervision, A.J.W.; funding acquisition, A.L. All authors have read and agreed to the published version of the manuscript.

Funding: Aaron Lim is supported by the European Union's Horizon 2020 research and innovation programme "iAtlantic" project ([grant number: 818123]) and Science Foundation Ireland project "MMMonKey_Pro" ([grant number: 16/IA/4528]) which is co-funded by the Geological Survey, Ireland and Marine Institute. Luis Conti is supported by FAPESP (Fundação de Amparo a Ciencia do Estado de São Paulo) ([grant number 2017/19649-8]).

Conflicts of Interest: The authors declare no conflict of interest.

\section{References}

1. Mayer, L.; Jakobsson, M.; Allen, G.; Dorschel, B.; Falconer, R.; Ferrini, V.; Lamarche, G.; Snaith, H.; Weatherall, P. The Nippon Foundation-GEBCO Seabed 2030 Project: The Quest to See the World's Oceans Completely Mapped by 2030. Geosciences 2018, 8, 63. [CrossRef]

2. Danovaro, R.; Dell'Anno, A.; Pusceddu, A. Biodiversity response to climate change in a warm deep sea. Ecol. Lett. 2004, 7, 821-828. [CrossRef]

3. Roberts, J.M.; Wheeler, A.J.; Cairns, S.; Freiwald, A. Cold-Water Corals: The Biology and Geology of Deep-Sea Coral Habitats; Cambridge University Press: Cambridge, UK, 2009.

4. Freiwald, A. Ocean Margin Systems; Wefer, G., Billet, D., Hebbeln, D., Jorgensen, B.B., Schlüter, M., Van Weering, T.C., Eds.; Hanse Conference Report; Springer: Berlin/Heidelberg, Germany, 2002; pp. 365-385.

5. Roberts, J.M.; Long, D.; Wilson, J.B.; Mortensen, P.B.; Gage, J.D. The cold-water coral Lophelia pertusa (Scleractinia) and enigmatic seabed mounds along the north-east Atlantic margin: Are they related? Mar. Pollut. Bull. 2003, 46, 7-20. [CrossRef]

6. Addamo, A.M.; Vertino, A.; Stolarski, J.; García-Jiménez, R.; Taviani, M.; Machordom, A. Merging scleractinian genera: The overwhelming genetic similarity between solitary Desmophyllum and colonial Lophelia. BMC Evolut. Biol. 2016, 16, 108.

7. Mienis, F.; Duineveld, G.C.A.; Davies, A.J.; Ross, S.W.; Seim, H.; Bane, J.; Van Weering, T.C.E. The influence of near-bed hydrodynamic conditions on cold-water corals in the Viosca Knoll area, Gulf of Mexico. Deep Sea Red. Part I Oceanogr. Res. Pap. 2012, 60, 32-45. [CrossRef]

8. Mienis, F.; de Stigter, H.C.; de Haas, H.; van Weering, T.C.E. Near-bed particle deposition and resuspension in a cold-water coral mound area at the Southwest Rockall Trough margin, NE Atlantic. Deep Sea Res. Part I 2009, 56, 1026-1038. [CrossRef]

9. Mienis, F.; de Stigter, H.C.; White, M.; Duineveld, G.; de Haas, H.; van Weering, T.C.E. Hydrodynamic controls on cold-water coral growth and carbonate-mound development at the SW and SE Rockall Trough Margin, NE Atlantic Ocean. Deep Sea Res. I 2007, 54, 1655-1674. [CrossRef]

10. De Clippele, L.H.; Huvenne, V.A.; Orejas, C.; Lundälv, T.; Fox, A.; Hennige, S.J.; Roberts, J.M. The effect of local hydrodynamics on the spatial extent and morphology of cold-water coral habitats at Tisler Reef, Norway. Coral Reefs 2018, 37, 253-266. [CrossRef]

11. Orejas, C.; Gori, A.; Rad-Menéndez, C.; Last, K.S.; Davies, A.J.; Beveridge, C.M.; Sadd, D.; Kiriakoulakis, K.; Witte, U.; Roberts, J.M. The effect of flow speed and food size on the capture efficiency and feeding behaviour of the cold-water coral Lophelia pertusa. J. Exp. Mar. Biol. Ecol. 2016, 481, 34-40. [CrossRef]

12. Wilson, J.B. "Patch" development of the deep-water coral Lophelia pertusa (L.) on the Rockall bank. J. Mar. Biol. Assoc. UK 1979, 59, 165-177. [CrossRef]

13. Thierens, M.; Titschack, J.; Dorschel, B.; Huvenne, V.A.; Wheeler, A.J.; Stuut, J.B.; O'donnell, R. The 2.6 Ma depositional sequence from the Challenger cold-water coral carbonate mound (IODP Exp. 307): Sediment contributors and hydrodynamic palaeo-environments. Mar. Geol. 2010, 271, 260-277. [CrossRef]

14. Titschack, J.; Thierens, M.; Dorschel, B.; Schulbert, C.; Freiwald, A.; Kano, A.; Takashima, C.; Kawagoe, N.; Li, X.; Expedition, I.O.D.P. Carbonate budget of a cold-water coral mound (Challenger Mound, IODP Exp. 307). Mar. Geol. 2009, 259, 36-46. [CrossRef]

15. Davies, J.S.; Guillaumont, B.; Tempera, F.; Vertino, A.; Beuck, L.; Ólafsdóttir, S.H.; Smith, C.J.; Fosså, J.H.; Van den Beld, I.M.J.; Savini, A.; et al. A new classification scheme of European cold-water coral habitats: Implications for ecosystem-based management of the deep sea. Deep Sea Res. Part II Top. Stud. Oceanogr. 2017, 145, 102-109. [CrossRef] 
16. Carlier, A.; Le Guilloux, E.; Olu, K.; Sarrazin, J.; Mastrototaro, F.; Taviani, M.; Clavier, J. Trophic relationships in a deep Mediterranean cold-water coral bank (Santa Maria di Leuca, Ionian Sea). Mar. Ecol. Progr. Ser. 2010, 397, 125-137. [CrossRef]

17. van Oevelen, D.; Duineveld, G.; Lavaleye, M.S.S.; Mienis, F.; Soetaert, K.; Heip, C. The cold-water coral community as a hot spot for carbon cycling on continental margins: A food-web analysis from Rockall Bank (northeast Atlantic). Limnol. Oceanogr. 2009, 54, 1829-1844. [CrossRef]

18. Duineveld, G.C.A.; Lavaleye, M.S.S.; Bergman, M.J.N.; de Stigter, H.C.; Mienis, F. Trophic structure of a cold-water coral mound community (Rockall Bank, NE Atlantic) in relation to the near-bottom particle supply and current regime. Bull. Mar. Sci. 2007, 81, 449-467.

19. Roberts, J.M.; Wheeler, A.J.; Freiwald, A. Reefs of the Deep: The Biology and Geology of Cold-Water Coral Ecosystems. Science 2006, 312, 543-547. [CrossRef]

20. Huvenne, V.A.I.; Bett, B.J.; Masson, D.G.; Le Bas, T.P.; Wheeler, A.J. Effectiveness of a deep-sea cold-water coral Marine Protected Area, following eight years of fisheries closure. Biol. Conserv. 2016, 200, 60-69. [CrossRef]

21. UNEP World Conservation Monitoring Centre, and Census of Marine Life on Seamounts (Programme). Data Analysis Working Group. Seamounts, Deep-Sea Corals and Fisheries: Vulnerability of Deep-Sea Corals to Fishing on Seamounts Beyond Areas of National Jurisdiction; UNEP-WCMC: Cambridge, UK, 2006.

22. Cordes, E.; Arnaud-Haond, S.; Bergstad, O.-A.; da Costa Falcão, A.P.; Freiwald, A.; Roberts, J.M.; Bernal, P. Cold-Water Corals. In The First Global Integrated Marine Assessment: World Ocean Assessment I; United Nations: New York, NY, USA, 2016.

23. Wölfl, A.C.; Snaith, H.; Amirebrahimi, S.; Devey, C.W.; Dorschel, B.; Ferrini, V.; Huvenne, V.A.; Jakobsson, M.; Jencks, J.; Johnston, G.; et al. Seafloor Mapping-The Challenge of a Truly Global Ocean Bathymetry. Front. Mar. Sci. 2019, 6, 283. [CrossRef]

24. De Oliveira Pires, D. The azooxanthellate coral fauna of Brazil. Bull. Mar. Sci. 2007, 81, 265-272.

25. Kitahara, M.V. Species richness and distribution of azooxanthellate Scleractinia in Brazil. Bull. Mar. Sci. 2007, 81, 497-518.

26. Le Guilloux, E.; Olu, K.; Bourillet, J.F.; Savoye, B.; Iglésias, S.P.; Sibuet, M. First observations of deep-sea coral reefs along the Angola margin. Deep Sea Res. Part II Top. Stud. Oceanogr. 2009, 56, 2394-2403. [CrossRef]

27. Buhl-Mortensen, P. Coral reefs in the Southern Barents Sea: Habitat description and the effects of bottom fishing. Mar. Biol. Res. 2017, 13, 1027-1040. [CrossRef]

28. Wells, J.W.; Hedgpeth, J.W. Treatise on Marine Ecology and Paleoecolog; Geological Society of America: Boulder, CO, USA, 1957; Volume 67V10.

29. Grasmueck, M.; Eberli, G.P.; Viggiano, D.A.; Correa, T.; Rathwell, G.; Luo, J. Autonomous underwater vehicle (AUV) mapping reveals coral mound distribution, morphology, and oceanography in deep water of the Straits of Florida. Geophys. Res. Lett. 2006, 33, L23616. [CrossRef]

30. Wheeler, A.J.; Beyer, A.; Freiwald, A.; De Haas, H.; Huvenne, V.A.I.; Kozachenko, M.; Olu-Le Roy, K.; Opderbecke, J. Morphology and environment of cold-water coral carbonate mounds on the NW European margin. Int. J. Earth Sci. 2007, 96, 37-56. [CrossRef]

31. Guinan, J.; Brown, C.; Dolan, M.F.J.; Grehan, A.J. Ecological niche modelling of the distribution of cold-water coral habitat using underwater remote sensing data. Ecol. Inf. 2009, 4, 83-92. [CrossRef]

32. Heindel, K.; Titschack, J.; Dorschel, B.; Huvenne, V.A.I.; Freiwald, A. The sediment composition and predictive mapping of facies on the Propeller Mound-A cold-water coral mound (Porcupine Seabight, NE Atlantic). Cont. Shelf Res. 2010, 30, 1814-1829. [CrossRef]

33. Huvenne, V.A.; Tyler, P.A.; Masson, D.G.; Fisher, E.H.; Hauton, C.; Hühnerbach, V.; Le Bas, T.P.; Wolff, G.A. A picture on the wall: Innovative mapping reveals cold-water coral refuge in submarine canyon. PLoS ONE 2011, 6, e28755. [CrossRef]

34. Huvenne, V.A.I.; Beyer, A.; de Haas, H.; Dekindt, K.; Henriet, J.-P.; Kozachenko, M. Cold-Water Corals and Ecosystems; André Freiwald, A., Murray Roberts, J., Eds.; Springer: Berlin/Heidelberg, Germany, 2005; pp. 535-569.

35. Mortensen, P.B.; Hovland, M.T.; Fosså, J.H.; Furevik, D.M. Distribution, abundance and size of Lophelia pertusa coral reefs in mid-Norway in relation to seabed characteristics. J. Mar. Biol. Assoc. UK 2001, 81, 581-597. [CrossRef]

36. Reed, J.K.; Weaver, D.C.; Pomponi, S.A. Habitat and fauna of deep-water Lophelia pertusa coral reefs off the southeastern U.S. Blake plateau, Straits of Florida, and Gulf of Mexico. Bull. Mar. Sci. 2006, 78, 343-375.

37. Savini, A.; Vertino, A.; Marchese, F.; Beuck, L.; Freiwald, A. Mapping cold-water coral habitats at different scales within the Northern Ionian Sea (Central Mediterranean): An assessment of coral coverage and associated vulnerability. PLoS ONE 2014, 9, e87108. [CrossRef] [PubMed]

38. Savini, A.; Corselli, C. High-resolution bathymetry and acoustic geophysical data from Santa Maria di Leuca Cold Water Coral province (Northern Ionian Sea-Apulian continental slope). Deep Sea Res. Part II Top. Stud. Oceanogr. 2010, 57, 326-344. [CrossRef]

39. Wheeler, A.; Bett, B.; Billett, D.; Masson, D. High resolution side-scan sonar mapping of deep-water coral mounds: Surface morphology and processes affecting growth. Eos Trans. Am. Geophys. Union 2000, 81, F638.

40. Wienberg, C.; Beuck, L.; Heidkamp, S.; Hebbeln, D.; Freiwald, A.; Pfannkuche, O.; Monteys, X. Franken Mound: Facies and biocoenoses on a newly-discovered "carbonate mound" on the western Rockall Bank, NE Atlantic. Facies 2008, 54, 1-24. [CrossRef]

41. Jarna, A.; Baeten, N.J.; Elvenes, S.; Bellec, V.K.; Thorsnes, T.; Diesing, M. Semi-Automatic Versus Manual Mapping of Cold-Water Coral Carbonate Mounds Located Offshore Norway. ISPRS Int. J. Geo Inf. 2019, 8, 40. [CrossRef] 
42. Lo Iacono, C.; Savini, A.; Huvenne, V.A.I.; Gràcia, E. Mediterranean Cold-Water Corals: Past, Present and Future: Understanding the Deep-Sea Realms of Coral; Orejas, C., Jiménez, C., Eds.; Springer International Publishing: Berlin/Heidelberg, Germany, 2019; pp. 157-171.

43. Angeletti, L.; Bargain, A.; Campiani, E.; Foglini, F.; Grande, V.; Leidi, E. Mediterranean Cold-Water Corals: Past, Present and Future: Understanding the Deep-Sea Realms of Coral; Orejas, C., Jiménez, C., Eds.; Springer International Publishing: Berlin/Heidelberg, Germany, 2019; pp. 173-189.

44. Bargain, A.; Foglini, F.; Pairaud, I.; Bonaldo, D.; Carniel, S.; Angeletti, L.; Taviani, M.; Rochette, S.; Fabri, M.C. Predictive habitat modeling in two Mediterranean canyons including hydrodynamic variables. Pogr. Oceanogr. 2018, 169, 151-168. [CrossRef]

45. Bargain, A.; Marchese, F.; Savini, A.; Taviani, M.; Fabri, M.-C. Santa Maria di Leuca Province (Mediterranean Sea): Identification of Suitable Mounds for Cold-Water Coral Settlement Using Geomorphometric Proxies and Maxent Methods. Front. Mar. Sci. 2017, 4, 338. [CrossRef]

46. Mata, D.; Muñoz, A.; Viscasillas, L.; Varas, D. Seafloor Geomorphology as Benthic Habitat, 2nd ed.; Harris, P.T., Baker, E., Eds.; Elsevier: Amsterdam, The Netherlands, 2020; pp. 721-734.

47. Prampolini, M.; Angeletti, L.; Grande, V.; Taviani, M.; Foglini, F. Seafloor Geomorphology as Benthic Habitat, 2nd ed.; Harris, P.T., Baker, E., Eds.; Elsevier: Amsterdam, The Netherlands, 2020; pp. 793-810.

48. Brown, C.J.; Smith, S.J.; Lawton, P.; Anderson, J.T. Benthic habitat mapping: A review of progress towards improved understanding of the spatial ecology of the seafloor using acoustic techniques. Estuar. Coast. Shelf Sci. 2011, 92, 502-520. [CrossRef]

49. Anderson, J.T.; Van Holliday, D.; Kloser, R.; Reid, D.G.; Simard, Y. Acoustic seabed classification: Current practice and future directions. ICES J. Mar. Sci. 2008, 65, 1004-1011. [CrossRef]

50. Brown, C.J.; Blondel, P. Developments in the application of multibeam sonar backscatter for seafloor habitat mapping. Appl. Acoust. 2009, 70, 1242-1247. [CrossRef]

51. Le Bas, T.P.; Huvenne, V.A.I. Acquisition and processing of backscatter data for habitat mapping-Comparison of multibeam and sidescan systems. Appl. Acoust. 2009, 70, 1248-1257. [CrossRef]

52. Pandian, P.K.; Ruscoe, J.P.; Shields, M.; Side, J.C.; Harris, R.E.; Kerr, S.A.; Bullen, C.R. Seabed habitat mapping techniques: An overview of the performance of various systems. Mediter. Mar. Sci. 2009, 10, 29-44. [CrossRef]

53. Van Rein, H.; Brown, C.; Quinn, R.; Breen, J. A review of sublittoral monitoring methods in temperate waters: A focus on scale. Underw. Technol. 2009, 28, 99-113. [CrossRef]

54. Freitas, R.; Ricardo, F.; Pereira, F.; Sampaio, L.; Carvalho, S.; Gaspar, M.; Quintino, V.; Rodrigues, A.M. Benthic habitat mapping: Concerns using a combined approach (acoustic, sediment and biological data). Estuar. Coast. Shelf Sci. 2011, 92, 598-606. [CrossRef]

55. Beyer, A.; Schenke, H.W.; Klenke, M.; Niederjasper, F. High resolution bathymetry of the eastern slope of the Porcupine Seabight. Mar. Geol. 2003, 198, 27-54. [CrossRef]

56. Hebbeln, D.; Wienberg, C.; Wintersteller, P.; Freiwald, A.; Becker, M.; Beuck, L.; Dullo, W.C.; Eberli, G.P.; Glogowski, S.; Matos, L.; et al. Environmental forcing of the Campeche cold-water coral province, southern Gulf of Mexico. Biogeosciences 2014, 11, 1799-1815. [CrossRef]

57. De Clippele, L.H.; Gafeira, J.; Robert, K.; Hennige, S.; Lavaleye, M.S.; Duineveld, G.C.A.; Huvenne, V.A.; Roberts, J.M. Using novel acoustic and visual mapping tools to predict the small-scale spatial distribution of live biogenic reef framework in cold-water coral habitats. Coral Reefs 2017, 36, 255-268. [CrossRef]

58. Roberts, J.M.; Brown, C.J.; Long, D.; Bates, C.R. Acoustic mapping using a multibeam echosounder reveals cold-water coral reefs and surrounding habitats. Coral Reefs 2005, 24, 654-669. [CrossRef]

59. Angeletti, L.; Castellan, G.; Montagna, P.; Remia, A.; Taviani, M. The "Corsica Channel Cold-Water Coral Province" (Mediterranean Sea). Front. Mar. Sci. 2020, 7, 661. [CrossRef]

60. Wienberg, C.; Titschack, J.; Freiwald, A.; Frank, N.; Lundälv, T.; Taviani, M.; Beuck, L.; Schröder-Ritzrau, A.; Krengel, T.; Hebbeln, D. The giant Mauritanian cold-water coral mound province: Oxygen control on coral mound formation. Quat. Sci. Rev. 2018, 185, 135-152. [CrossRef]

61. Dorschel, B.; Wheeler, A.J.; Monteys, X.; Verbruggen, K. Atlas of the Deep-Water Seabed: Ireland; Springer: Berlin/Heidelberg, Germany, 2010.

62. Wheeler, A.J.; Beck, T.; Thiede, J.; Klages, M.; Grehan, A.; Monteys, F.X. Cold-Water Corals and Ecosystems; Freiwald, A., Murray Roberts, J., Eds.; Springer: Berlin/Heidelberg, Germany, 2005; pp. 393-402.

63. Huvenne, V.A.I.; Blondel, P.; Henriet, J.-P. Textural analyses of sidescan sonar imagery from two mound provinces in the Porcupine Seabight. Mar. Geol. 2002, 189, 323-341. [CrossRef]

64. Dorschel, B.; Wheeler, A.J.; Huvenne, V.A.I.; de Haas, H. Cold-water coral mounds in an erosive environmental setting: TOBI side-scan sonar data and ROV video footage from the northwest Porcupine Bank, NE Atlantic. Mar. Geol. 2009, 264, 218-229. [CrossRef]

65. Lim, A.; Huvenne, V.A.I.; Vertino, A.; Spezzaferri, S.; Wheeler, A.J. New insights on coral mound development from groundtruthed high-resolution ROV-mounted multibeam imaging. Mar. Geol. 2018, 403, 225-237. [CrossRef]

66. Foubert, A.T.G.; Huvenne, V.A.I.; Wheeler, A.J.; Kozachenko, M.; Opderbecke, J.; Henriet, J.-P. The Moira Mounds, small cold-water coral mounds in the Porcupine Seabight, NE Atlantic: Part B-Evaluating the impact of sediment dynamics through high-resolution ROV-borne bathymetric mapping. Mar. Geol. 2011, 282, 65-78. [CrossRef] 
67. Purser, A.; Bergmann, M.; Lundälv, T.; Ontrup, J.; Nattkemper, T.W. Use of machine-learning algorithms for the automated detection of cold-water coral habitats: A pilot study. Mar. Ecol. Progr. Ser. 2009, 397, 241-251. [CrossRef]

68. Appah, J.K.M.; Lim, A.; Harris, K.; O'Riordan, R.; O'Reilly, L.; Wheeler, A.J. Are Non-reef Habitats as Important to Benthic Diversity and Composition as Coral Reef and Rubble Habitats in Submarine Canyons? Analysis of Controls on Benthic Megafauna Distribution in the Porcupine Bank Canyon, NE Atlantic. Front. Mar. Sci. 2020, 7. [CrossRef]

69. Vertino, A.; Savini, A.; Rosso, A.; Di Geronimo, I.; Mastrototaro, F.; Sanfilippo, R.; Gay, G.; Etiope, G. Benthic habitat characterization and distribution from two representative sites of the deep-water SML Coral Province (Mediterranean). Deep Sea Res. Part II 2010, 57, 380-396. [CrossRef]

70. Dorschel, B.; Hebbeln, D.; Foubert, A.T.G.; White, M.; Wheeler, A.J. Hydrodynamics and cold-water coral facies distribution related to recent sedimentary processes at Galway Mound west of Ireland. Mar. Geol. 2007, 244, 184-195. [CrossRef]

71. Dolan, M.F.J.; Grehan, A.J.; Guinan, J.C.; Brown, C. Modelling the local distribution of cold-water corals in relation to bathymetric variables: Adding spatial context to deep-sea video data. Deep Sea Res. I 2008, 55, 1564-1579. [CrossRef]

72. Wheeler, A.J.; Kozachenko, M.; Henry, L.A.; Foubert, A.; De Haas, H.; Huvenne, V.A.I.; Masson, D.G.; Olu, K. The Moira Mounds, small cold-water coral banks in the Porcupine Seabight, NE Atlantic: Part A-An early stage growth phase for future coral carbonate mounds? Mar. Geol. 2011, 282, 53-64. [CrossRef]

73. Lim, A.; Wheeler, A.J.; Arnaubec, A. High-resolution facies zonation within a cold-water coral mound: The case of the Piddington Mound, Porcupine Seabight, NE Atlantic. Mar. Geol. 2017, 390, 120-130. [CrossRef]

74. Pizarro, O.; Friedman, A.; Bryson, M.; Williams, S.B.; Madin, J. A simple, fast, and repeatable survey method for underwater visual 3D benthic mapping and monitoring. Ecol. Evol. 2017, 7, 1770-1782. [CrossRef] [PubMed]

75. Price, D.M.; Robert, K.; Callaway, A.; Lo lacono, C.; Hall, R.A.; Huvenne, V.A.I. Using 3D photogrammetry from ROV video to quantify cold-water coral reef structural complexity and investigate its influence on biodiversity and community assemblage. Coral Reefs 2019, 38, 1007-1021. [CrossRef]

76. Robert, K.; Huvenne, V.A.; Georgiopoulou, A.; Jones, D.O.; Marsh, L.; Carter, G.D.; Chaumillon, L. New approaches to highresolution mapping of marine vertical structures. Sci. Rep. 2017, 7, 9005. [CrossRef]

77. Chitre, M.; Shahabudeen, S.; Stojanovic, M. Underwater acoustic communications and networking: Recent advances and future challenges. Mar. Technol. Soc. J. 2008, 42, 103-116. [CrossRef]

78. Kinsey, J.C.; Eustice, R.M.; Whitcomb, L.L. IFAC Conference of Manoeuvering and Control of Marine Craft; IFAC: Lisbon, Portugal, 2006.

79. Boolukos, C.M.; Lim, A.; O'Riordan, R.M.; Wheeler, A.J. Cold-water corals in decline-A temporal (4 year) species abundance and biodiversity appraisal of complete photomosaiced cold-water coral reef on the Irish Margin. Deep Sea Red. Part I Oceanogr. Res. Pap. 2019, 146, 44-54. [CrossRef]

80. Lim, A.; Kane, A.; Arnaubec, A.; Wheeler, A.J. Seabed image acquisition and survey design for cold water coral mound characterisation. Mar. Geol. 2018, 395, 22-32. [CrossRef]

81. Bennecke, S.; Kwasnitschka, T.; Metaxas, A.; Dullo, W.-C. In situ growth rates of deep-water octocorals determined from 3D photogrammetric reconstructions. Coral Reefs 2016, 35, 1227-1239. [CrossRef]

82. Goodchild, M.F.; Haining, R.P. GIS and spatial data analysis: Converging perspectives. Pap. Reg. Sci. 2004, 83, 363-385. [CrossRef]

83. Wheeler, A.J.; Kozachenko, M.; Beyer, A.; Foubert, A.T.G.; Huvenne, V.A.I.; Klages, M. Cold-Water Corals and Ecosystems; Freiwald, A., Murray Roberts, J., Eds.; Springer: Berlin/Heidelberg, Germany, 2005; pp. 533-564.

84. Beyer, A.; Chakraborty, B.; Schenke, H.W. Seafloor classification of the mound and channel provinces of the Porcupine Seabight: An application of the multibeam angular backscatter data. Int. J. Earth Sci. 2007, 96, 11-20. [CrossRef]

85. Davies, A.J.; Wisshak, M.; Orr, J.C.; Roberts, J.M. Predicting suitable habitat for the cold-water coral Lophelia pertusa (Scleractinia). Deep Sea Res. I 2008, 55, 1048-1062. [CrossRef]

86. Smith Menandro, P.; Cardoso Bastos, A. Seabed Mapping: A Brief History from Meaningful Words. Geosciences 2020, 10, 273. [CrossRef]

87. De Mol, B.; Van Rensbergen, P.; Pillen, S.; Van Herreweghe, K.; Van Rooij, D.; McDonnell, A.; Huvenne, V.A.I.; Ivanov, M.K.; Swennen, R.; Henriet, J.-P. Large deep-water coral banks in the Porcupine Basin, southwest of Ireland. Mar. Geol. 2002, 188, 193-231. [CrossRef]

88. Freiwald, A.; Hühnerbach, V.; Lindberg, B.; Wilson, J.B.; Campbell, J. The Sula Reef Complex, Norwegian shelf. Facies 2002, 47, 179-200. [CrossRef]

89. Masson, D.G.; Bett, B.J.; Billett, D.S.M.; Jacobs, C.L.; Wheeler, A.J.; Wynn, R.B. The origin of deep-water, coral-topped mounds in the northern Rockall Trough, Northeast Atlantic. Mar. Geol. 2003, 194, 159-180. [CrossRef]

90. O'Reilly, B.M.; Readman, P.W.; Shannon, P.M.; Jacob, A.W.B. A model for the development of a carbonate mound population in the Rockall Trough based on deep-towed sidescan sonar data. Mar. Geol. 2003, 198, 55-66. [CrossRef]

91. Kenyon, N.H.; Akhmetzhanov, A.M.; Wheeler, A.J.; van Weering, T.C.E.; de Haas, H.; Ivanov, M.K. Giant carbonate mounds in the southern Rockall Trough. Mar. Geol. 2003, 195, 3-50. [CrossRef]

92. Akhmanov, G.G.; Premoli Silva, I.; Erba, E.; Cita, M.B. Sedimentary succession and evolution of the Mediterranean Ridge western sector as derived from lithology of mud breccia clasts. Mar. Geol. 2003, 195, 277-299. [CrossRef]

93. Foubert, A.T.G.; Beck, T.; Wheeler, A.J.; Opderbecke, J.; Grehan, A.; Klages, M.; Thiede, J.; Henriet, J.-P. Polarstern ARK-XIX/3a shipboard party. In Deep-Water Corals and Ecosystems; Freiwald, A., Roberts, J.M., Eds.; Springer: Heidelberg, Germany, 2005; pp. $403-415$. 
94. Mienis, F.; van Weering, T.C.E.; de Haas, H.; de Stigter, H.C.; Huvenne, V.A.I.; Wheeler, A.J. Carbonate mound development at the SW Rockall Trough margin based on high resolution TOBI and seismic recording. Mar. Geol. 2006, 233, 1-19. [CrossRef]

95. De Mol, B.; Kozachenko, M.; Wheeler, A.J.; Alvares, H.; Henriet, J.-P.; Olu-Le Roy, K. Thérèse Mound: A case study of coral bank development in the Belgica Mound Province, Porcupine Seabight. Int. J. Earth Sci. 2007, 96, 103-120. [CrossRef]

96. Wheeler, A.J.; Kozachenko, M.; Masson, D.G.; Huvenne, V.A.I. Influence of benthic sediment transport on cold-water coral bank morphology and growth: The example of the Darwin Mounds, north-east Atlantic. Sedimentology 2008, 55, 1875-1887. [CrossRef]

97. Wienberg, C.; Hebbeln, D.; Fink, H.G.; Mienis, F.; Dorschel, B.; Vertino, A.; López Correa, M.; Freiwald, A. Scleractinian cold-water corals in the Gulf of Cádiz-first clues about their spatial and temporal distribution. Deep Sea Res. Part I Oceanogr. Res. Pap. 2009, 56, 1873-1893. [CrossRef]

98. Guinan, J.; Grehan, A.J.; Dolan, M.F.J.; Brown, C. Quantifying relationships between video observations of cold-water coral cover and seafloor features in Rockall Trough, west of Ireland. Mar. Ecol. Prog. Ser. 2009, 375, 125-138. [CrossRef]

99. Davies, A.J.; Duineveld, G.C.A.; van Weering, T.C.E.; Mienis, F.; Quattrini, A.M.; Seim, H.E.; Bane, J.M.; Ross, S.W. Short-term environmental variability in cold-water coral habitat at Viosca Knoll, Gulf of Mexico. Deep Sea Res. Part I Oceanogr. Res. Pap. 2010, 57, 199-212. [CrossRef]

100. Coiras, E.; Iacono, C.L.; Gracia, E.; Danobeitia, J.; Sanz, J.L. Automatic Segmentation of Multi-Beam Data for Predictive Mapping of Benthic Habitats on the Chella Seamount (North-Eastern Alboran Sea, Western Mediterranean). IEEE J. Sel. Top. Appl. Earth Obs. Remote Sens. 2011, 4, 809-813. [CrossRef]

101. Correa, T.B.S.; Eberli, G.P.; Grasmueck, M.; Reed, J.K.; Correa, A.M.S. Genesis and morphology of cold-water coral ridges in a unidirectional current regime. Mar. Geol. 2012, 326, 14-27. [CrossRef]

102. Correa, T.B.S.; Grasmueck, M.; Eberli, G.P.; Reed, J.K.; Verwer, K.; Purkis, S.A.M. Variability of cold-water coral mounds in a high sediment input and tidal current regime, Straits of Florida. Sedimentology 2012, 59, 1278-1304. [CrossRef]

103. Mazzini, A.; Akhmetzhanov, A.; Monteys, X.; Ivanov, M. The Porcupine Bank Canyon coral mounds: Oceanographic and topographic steering of deep-water carbonate mound development and associated phosphatic deposition. Geo Mar. Lett. 2012, 32, 205-225. [CrossRef]

104. Harris, P.T.; Nichol, S.L.; Anderson, T.J.; Heap, A.D. Seafloor Geomorphology as Benthic Habitat: GeoHab Atlas of Seafloor Geomorphic Features and Benthic Habitats; Harris, P.T., Baker, E.K., Eds.; Elsevier: Amsterdam, The Netherlands, 2012; pp. 777-789.

105. Muñoz, A.; Cristobo, J.; Rios, P.; Druet, M.; Polonio, V.; Uchupi, E.; Acosta, J. Sediment drifts and cold-water coral reefs in the Patagonian upper and middle continental slope. Mar. Petrol. Geol. 2012, 36, 70-82. [CrossRef]

106. Wienberg, C.; Wintersteller, P.; Beuck, L.; Hebbeln, D. Coral Patch seamount (NE Atlantic)—A sedimentological and megafaunal reconnaissance based on video and hydroacoustic surveys. Biogeosciences 2013, 10, 3421-3443. [CrossRef]

107. Mienis, F.; Duineveld, G.C.A.; Davies, A.J.; Lavaleye, M.M.S.; Ross, S.W.; Seim, H.; Bane, J.; van Haren, H.; Bergman, M.J.N.; de Haas, H.; et al. Cold-water coral growth under extreme environmental conditions, the Cape Lookout area, NW Atlantic. Biogeosciences 2014, 11, 2543-2560. [CrossRef]

108. Brooke, S.; Ross, S.W. First observations of the cold-water coral Lophelia pertusa in mid-Atlantic canyons of the USA. Deep Sea Res. Part II Top. Stud. Oceanogr. 2014, 104, 245-251. [CrossRef]

109. Lo Iacono, C.; Gràcia, E.; Ranero, C.R.; Emelianov, M.; Huvenne, V.A.I.; Bartolomé, R.; Booth-Rea, G.; Prades, J.; Ambroso, S.; Dominguez, C.; et al. The West Melilla cold water coral mounds, Eastern Alboran Sea: Morphological characterization and environmental context. Deep Sea Res. Part II Top. Stud. Oceanogr. 2014, 99, 316-326. [CrossRef]

110. Neves, B.M.; Du Preez, C.; Edinger, E. Mapping coral and sponge habitats on a shelf-depth environment using multibeam sonar and ROV video observations: Learmonth Bank, northern British Columbia, Canada. Deep Sea Res. Part II Top. Stud. Oceanogr. 2014, 99, 169-183. [CrossRef]

111. Somoza, L.; Ercilla, G.; Urgorri, V.; León, R.; Medialdea, T.; Paredes, M.; Gonzalez, F.J.; Nombela, M.A. Detection and mapping of cold-water coral mounds and living Lophelia reefs in the Galicia Bank, Atlantic NW Iberia margin. Mar. Geol. 2014, 349, 73-90. [CrossRef]

112. Mackay, K.A.; Rowden, A.A.; Bostock, H.C.; Tracey, D.M. Revisiting Squires' Coral Coppice, Campbell Plateau, New Zealand. N. Z. J. Mar. Freshwater Res. 2014, 48, 507-523. [CrossRef]

113. Stewart, H.A.; Davies, J.S.; Guinan, J.; Howell, K.L. The Dangeard and Explorer canyons, South Western Approaches UK: Geology, sedimentology and newly discovered cold-water coral mini-mounds. Deep Sea Research Part II Top. Stud. Oceanogr. 2014, 104, 230-244. [CrossRef]

114. Robert, K.; Jones, D.O.B.; Roberts, J.M.; Huvenne, V.A.I. Improving predictive mapping of deep-water habitats: Considering multiple model outputs and ensemble techniques. Deep Sea Res. Part I Oceanogr. Res. Pap. 2016, 113, 80-89. [CrossRef]

115. Vandorpe, T.; Martins, I.; Vitorino, J.; Hebbeln, D.; García, M.; Van Rooij, D. Bottom currents and their influence on the sedimentation pattern in the El Arraiche mud volcano province, southern Gulf of Cadiz. Mar. Geol. 2016, 378, 114-126. [CrossRef]

116. Ramos, A.; Sanz, J.L.; Ramil, F.; Agudo, L.M.; Presas-Navarro, C. Deep-Sea Ecosystems Off Mauritania: Research of Marine Biodiversity and Habitats in the Northwest African Margin; Ramos, A., Ramil, F., Sanz, J.L., Eds.; Springer: Dordrecht, The Netherlands, 2017; pp. 481-525.

117. Reolid, J.; Reolid, M.; Betzler, C.; Lindhorst, S.; Wiesner, M.G.; Lahajnar, N. Upper Pleistocene cold-water corals from the Inner Sea of the Maldives: Taphonomy and environment. Facies 2017, 63, 8. [CrossRef] 
118. Collart, T.; Verreydt, W.; Hernández-Molina, F.J.; Llave, E.; León, R.; Gómez-Ballesteros, M.; Pons-Branchu, E.; Stewart, H.; Van Rooij, D. Sedimentary processes and cold-water coral mini-mounds at the Ferrol canyon head, NW Iberian margin. Pogr. Oceanogr. 2018, 169, 48-65. [CrossRef]

119. Diesing, M.; Thorsnes, T. Mapping of Cold-Water Coral Carbonate Mounds Based on Geomorphometric Features: An ObjectBased Approach. Geosciences 2018, 8, 34. [CrossRef]

120. Conti, L.A.; Lim, A.; Wheeler, A.J. High resolution mapping of a cold water coral mound. Sci. Rep. 2019, 9, 1016. [CrossRef] [PubMed]

121. Hebbeln, D.; Bender, M.; Gaide, S.; Titschack, J.; Vandorpe, T.; Van Rooij, D.; Wintersteller, P.; Wienberg, C. Thousands of cold-water coral mounds along the Moroccan Atlantic continental margin: Distribution and morphometry. Mar. Geol. 2019, 411, 51-61. [CrossRef]

122. Lim, A.; Wheeler, A.J.; Price, D.M.; O’Reilly, L.; Harris, K.; Conti, L. Influence of benthic currents on cold-water coral habitats: A combined benthic monitoring and 3D photogrammetric investigation. Sci. Rep. 2020, 10, 19433. [CrossRef]

123. Kenyon, N.H.; Ivanov, M.K.; Akhmetzhanov, A.M. IOC Technical Series 52; 178; UNESCO: Paris, France, 1998.

124. Rezak, R.; Bright, T.J.; McGrail, D.W. Reefs and Banks of the Northwestern Gulf of Mexico: Their Geological, Biological, and Physical Dynamics; Wiley: Hoboken, NJ, USA, 1985.

125. Hovland, M.; Thomsen, E. Cold-water corals-Are they hydrocarbon seep related? Mar. Geol. 1997, 137, 159-164. [CrossRef]

126. Kocak, D.M.; Caimi, F.M. The Current Art of Underwater Imaging-With a Glimpse of the Past and Vision of the Future. Mar. Technol. Soc. J. 2005, 39, 5-26. [CrossRef]

127. Hu, S.; Sprintall, J.; Guan, C.; McPhaden, M.J.; Wang, F.; Hu, D.; Cai, W. Deep-reaching acceleration of global mean ocean circulation over the past two decades. Sci. Adv. 2020, 6, eaax7727. [CrossRef]

128. Diesing, M.; Mitchell, P.; Stephens, D. Image-based seabed classification: What can we learn from terrestrial remote sensing? ICES J. Mar. Sci. 2016, 73, 2425-2441. [CrossRef]

129. Lucieer, V.; Roche, M.; Degrendele, K.; Malik, M.; Dolan, M.; Lamarche, G. User expectations for multibeam echo sounders backscatter strength data-looking back into the future. Mar. Geophys. Res. 2018, 39, 23-40. [CrossRef]

130. Lamarche, G.; Lurton, X. Recommendations for improved and coherent acquisition and processing of backscatter data from seafloor-mapping sonars. Mar. Geophys. Res. 2018, 39, 5-22. [CrossRef]

131. Hovland, M.; Risk, M. Do Norwegian deep-water coral reefs rely on seeping fluids? Mar. Geol. 2003, 198, 83-96. [CrossRef]

132. Durden, J.M.; Bett, B.J.; Schoening, T.; Morris, K.J.; Nattkemper, T.W.; Ruhl, H.A. Comparison of image annotation data generated by multiple investigators for benthic ecology. Mar. Ecol. Progr. Ser. 2016, 552, 61-70. [CrossRef]

133. Costello, M.J. Distinguishing marine habitat classification concepts for ecological data management. Mar. Ecol. Progr. Ser. 2009, 397, 253-268. [CrossRef]

134. Masetti, G.; Mayer, L.A.; Ward, L.G. A bathymetry-and reflectivity-based approach for seafloor segmentation. Geosciences 2018, 8, 14. [CrossRef]

135. Jasiewicz, J.; Stepinski, T.F. Geomorphons-A pattern recognition approach to classification and mapping of landforms. Geomorphology 2013, 182, 147-156. [CrossRef]

136. ArcGIS Benthic Terrain Modeler: Collection of Tools Used with Bathymetric Data Sets to Examine the Deepwater Benthic Environment; Oregon State University, Davey Jones' Locker Seafloor Mapping/Marine GIS Laboratory and NOAA Coastal Services Center: Corvallis, OR, USA, 2005.

137. Lastras, G.; Canals, M.; Ballesteros, E.; Gili, J.-M.; Sanchez-Vidal, A. Cold-Water Corals and Anthropogenic Impacts in La Fonera Submarine Canyon Head, Northwestern Mediterranean Sea. PLoS ONE 2016, 11, e0155729. [CrossRef]

138. Serrano, A.; González-Irusta, J.M.; Punzón, A.; García-Alegre, A.; Lourido, A.; Ríos, P.; Blanco, M.; Gómez-Ballesteros, M.; Druet, M.; Cristobo, J.; et al. Deep-sea benthic habitats modeling and mapping in a NE Atlantic seamount (Galicia Bank). Deep Sea Red. Part I Oceanogr. Res. Papers 2017, 126, 115-127. [CrossRef]

139. Chen, G.; Weng, Q.; Hay, G.J.; He, Y. Geographic object-based image analysis (GEOBIA): Emerging trends and future opportunities. GISci. Remote Sens. 2018, 55, 159-182. [CrossRef]

140. Lang, S.; Schöpfer, E.; Hölbling, D.; Blaschke, T.; Moeller, M.; Jekel, T. Use of Landscape Sciences for the Assessment of Environmental Security; Petrosillo, I., Müller, F., Jones, K.B., Zurlini, G., Krauze, K., Victorov, S., Li, B.L., Kepner, W.G., Eds.; Springer: Berlin/Heidelberg, Germany, 2008; pp. 93-105.

141. Thessen, A.E. Adoption of Machine Learning Techniques in Ecology and Earth Science. One Ecosyst. 2016, 1, e8621. [CrossRef]

142. Osterloff, J.; Nilssen, I.; Järnegren, J.; Van Engeland, T.; Buhl-Mortensen, P.; Nattkemper, T.W. Computer vision enables shortand long-term analysis of Lophelia pertusa polyp behaviour and colour from an underwater observatory. Sci. Rep. 2019 , 9, 6578. [CrossRef] [PubMed] 